\title{
Developing a global South perspective of street children's involvement in organized crime
}

Sally Atkinson-Sheppard

The majority of studies about gangs come from the global North meaning that we know very little about young people's involvement in organized crime in the global South. This chapter explores the roles that Bangladeshi street children play organized crime groups by drawing on interviews with street children, criminal justice practitioners, non-government organization workers and community members, and over three years of participant observation of Bangladesh and its criminal justice system. This paper argues that in order to understand street children's involvement in Bangladesh's organized crime groups - the mastaans - it is necessary to expand the boundaries of criminology to include development studies' concepts of social protection, patron-clientism and child labor. The chapter highlights the need to build a more cohesive collaboration between criminology and development studies.

Key words: Street children, organized crime, gangs, Bangladesh, global South, Southern criminology

\section{Introduction}

Over three quarters of the world live in the global South yet criminology has focused most of its efforts of explaining crime and violence in the global North (Carrington, Hogg and Sozzo 2016). In order to develop global approaches to crime scholars must first discuss a Southern criminology (Carrington, Hogg and Sozzo 2016). Carrington, Hogg and Sozzo (2016) draw on Connell's (2007) Southern theory to demonstrate the inequality that often arises from both the historical origins and implementation of criminology. They propose that 'the North/South distinction refers to the divide between the metropolitan states of Western Europe and North America, on the one hand, and the countries of Latin America, Africa, Asia and Oceania, on the other' (Carrington, Hogg and Sozzo 2016: 2) and argue that issues salient to the global South are frequently underrepresented in criminological discourse.

Nelken's (2009: 292) discussions of ethnocentrism 'assuming that what we do, our way of thinking about and responding to crime, is universally shared or, at least, that it would be right for everyone else' has posed some of the greatest difficulties for the comparative criminologist. Said (1978) proposed that Western conceptualizations of Eastern societies were 'Orientalist' and that colonialists distorted the reality of life in the East. Cain (2000: 239) applied this concept to analysis of crime in the Caribbean. She argued that there are 'twin failings of Western criminology: orientalism, which romanticises the other, and 
occidentialism, which denies the possibility of difference, or seeks to explain it away'. Cain concluded that "the theoretical presumptions of Western criminology were as likely to be misleading or at best to miss the point' (Cain 2000: 239). As Connell (2007: ix) writes: 'the majority world does produce theory', yet this 'Southern theory' fails to receive the attention it deserves, in the 'North' and on a global scale.

Criminology suffers from a certain ethnocentricity in that it was, and is, largely conducted in the Western world. What does this mean for the development of the discipline? Firstly, there is a general consensus that something must be done to address the North/South divide (Carrington, Hogg and Sozzo 2016) to overcome issues of ethnocentrism and relativism in comparative criminology (Nelken 2009) and to avoid the trappings of Orientalism and Occidentalism in research (Cain 2000).

Development studies has evolved on a parallel trajectory; it is often multi-disciplinary and concerned with challenges facing the global South (i.e. poverty, inequality, child labor). Yet it is rare for discussions about crime and violence to feature extensively. Several scholars note the challenges of moving Southern criminology out of the theoretical domain and into mainstream debate (Travers 2016). One way of doing so is to build better academic and practical collaborations between criminology and development studies. To explore this further, this chapter uses an ethnographic case study of street children's involvement in organised crime. By drawing on 22 interviews with street children, 80 interviews with criminal justice practitioners, non-government organization (NGO) workers and community members and over three years of participant observation, and over three years of participant observation of Bangladesh and its criminal justice system, the chapter aims to provide an account of the ways in which organized crime groups in Bangladesh operate, the hierarchies that exist among them and the crimes they commit. This study combines concepts often associated with criminology (gangs and organized crime) with concepts usually associated development studies concepts (patronage, social protection and child labor) ${ }^{\mathrm{i}}$. Using this synthesis of concepts, the chapter discusses the following propositions: 1) Mastaans are mafia groups that operate in a market for protection, patronage and violence; 2) These groups hire street children to commit crime for them. The term 'illicit child laborer' is therefore useful in this context. The chapter concludes by considering implications for further research and how these discussions help to frame the development of a criminology suitable for explaining crime and violence on a global scale. 


\section{Organized crime, gangs and street children}

The majority of studies about gangs come from the global North meaning that we know very little about young people's involvement in organized crime in the global South, particularly in Bangladesh. Academic research about gangs and organized crime is generally welldeveloped in the West. The discourse is historically located in America dating back to the 1920s and Chicago School theories that form the basis for most gang debates today. Concepts fundamental to this work include: social disorganization, subcultural theories of crime, and urbanization (Thrasher 1927; Park, Burgess and McKenzie 1925).

Debate over what constitutes organized crime has featured in criminological discourse for decades, and there are various understandings of organized crime groups (Varese 2010). The first is the Cressey Model often associated with La Cosa Nostra and hierarchically structured criminal groups (Cressey 1967: 107). The second is the Enterprise Model that views crime through an economic lens; in this model, organized crime is largely focused on monopolizing criminal markets to accrue profit (Smith 1975). The third model is the Network Model, resulting from the inclusion of network analysis into discussions of organized crime. As scholars such as McIllwain (1999) propose, it is the spatial relationships between members within organized crime groups which helps to explain the nature of these criminal enterprises.

Many scholars propose that the Mafia are the epitome of organized crime groups (Gambetta 1993). However, the notion of 'the Mafia' is questioned by many, including Blok (1974) who argues that mafias are instead groups of small, and often interlinked individuals: Mafiosi. Mafias engage in a variety of crime (Paoli 2002; Wright 2006) yet what distinguishes mafias from organized crime groups in general is their relationship with the state and their ability to govern and monopolize the market for protection (Gambetta 1993; Varese 2001). Gambetta (1993) and Varese (2001) argue that in the context of weak states (or pockets of weakness in strong states) the mafias conduct illegal economic transactions, resolve disputes and provide protection for illegal industries. Sergi (2015) takes this further and argues that mafias engage in 'concurrent governance', working alongside - and intertwined - with corrupt members of the state.

It is important to explore the hierarchical relationship between members of an organized crime group in order to understand how these entities operate (McIntosh 1975). There is a 
general consensus that these groups are hierarchically structured (Hallsworth and Young 2006) and that organized criminals (and mafias) carry out their business by using gang members on the streets. Yet, despite the extent of this knowledge there is often a lacuna between studies of the gang and theories of organized crime. There is a general, and often pervasive argument within criminology that separates the two. A more balanced approach, and one that is more suitable for discussing 'global gangs', is one that positions gangs on a spectrum of organized crime (as argued by Hallsworth and Young 2006; Densley 2012).

Very little is known about street children's involvement in gangs or organized crime groups. ${ }^{\text {ii }}$ This is a striking omission, based on the fact that millions of children live on the streets and are vulnerable to the advances of organized crime. Research into street children largely focuses on poverty and marginalization (Ennew and Swart-Kruger 2003) but rarely considers young people's associations with illicit enterprises. Research into gangs is predominantly conducted in the North and research into organized crime is largely concerned with adult perspectives (Gambetta 1993; Varese 2010) meaning children's views are often overlooked.

\section{Bangladesh}

Bangladesh gained its independence and emerged as a nation in 1971, following a bloody war with Pakistan (Lewis 2012). Before this, what is now Bangladesh was East Pakistan, and even earlier was part of India, referred to as East Bengal (van Schendel 2009). Since 1971, Bangladesh has experienced several military coups and a consistent struggle for power between the country's two main political parties: the Awami League (AL) and the Bangladesh National Party (BNP) (Jahan 2001). Bangladesh's political situation is characterized by partisan politics, corruption and political violence (Feldman 1997; White 1999). It is a common occurrence for political disputes to be held on the streets of Bangladesh both within and between political parties (Moniruzzaman 2009).

There is an additional element to the Bangladeshi context: 'State building in Bangladesh remains a work in progress' meaning that a number of non-state actors engage in governance (Lewis 2012:172). These non-state actors range from small organizations that work in rural areas or 'home grown development NGOs' (Lewis 2012:172) to more expansive, country-wide and international corporations including the United Kingdom Department for International Development (DFID), the United Stated Agency for International Development (USAID), the United Nations (UN) and the World Bank (Lewis 
2012). Some associate this extensive donor support with a failure of the state to govern effectively (Feldman 1997; White 1999) and Lewis (2012: 173) argues that the size and capacity of some of the larger NGOs suggest that they operate as a 'parallel state'. This provides an essential component to understanding political and social spheres in Bangladesh largely because welfare services are rarely delivered by the state alone but by a 'plurality of providers' (Barrientos and Hulme 2008: 5). Even the most basic of services, such as education and healthcare, are often implemented by NGOs (Lewis 2012).

Bangladesh is a developing (Lewis 2012) Muslim majority country (Lewis 2012) with a population of around 164 million, over half of whom live in poverty (United Nations Human Settlements Programme [UN-HABITAT] 2002). The capital, Dhaka, houses nearly 16 million people and most citizens - approximately 10 million - live in slums (UN-HABITAT 2003). Poor areas of the city are overcrowded, and lack basic resources and sanitation systems (UN-HABITAT 2003). Children suffer the most; there are millions of children who live in slums or on the streets and experience abject poverty and acute marginalization (AusAID 2005). Child labor is pervasive (United Nations International Children's Emergency Fund [UNICEF] 2012a), trafficking prevalent (UNICEF 2012b) and children's rights are rarely protected (UNICEF 2012a).

There are three main concepts, derived from development studies, that can help frame discussions of street children's involvement in organized crime in Bangladesh. They are: social protection, patron-clientism and child labor. The first concept, social protection, 'refers to policies and actions which enhance the capacity of poor and vulnerable people to escape from poverty and enable them to better manage risks and shocks' (OECD 2009: 12). Thus, social protection promotes access to job opportunities, the labor market and basic services, and enables vulnerable people to increase their agency which in turn promotes ways out of intergenerational poverty (Barrientos and Hulme 2008). Importantly, for these discussions, social protection can be delivered by service providers which encompass more than just the state (i.e. NGOs), and organized crime groups.

Social protection in Bangladeshi policy and practice is established and relatively effective (World Bank 2012). The country has seen successes ranging from support for women and girls via the 'Female Secondary School Stipend Programme' to private sector influence in the country's world famous micro credit program implemented by Grameen Bank (World Bank 
2012). However, many of the country's citizens remain marginalized, including street children and child laborers (World Bank 2012). A 'patchwork approach' to social protection fails to reach many of the country's most marginalized and vulnerable groups (World Bank 2012). The majority of the effort is directed towards the rural poor, leaving those in urban areas unsupported and the government unprepared to deliver effective programs in towns and cities (World Bank 2012). Community based interventions are rare leaving vulnerable groups, such as street children, unable to access such services (World Bank 2012). This means that those who are arguably the most vulnerable, street children, or child workers, are also those that receive the least support (World Bank 2012).

Secondly, the nature of social connections defines how life is negotiated in Bangladesh and patronage is an essential component for understanding how these relationships operate. Patronage is important because, as Lewis (2012: 156) argues, 'patron-client relationships are a cornerstone of society in Bengal, combining political, economic and religious elements of social organisation'. This means that almost everything in Bangladeshi society is influenced by some level of patronage. A defining feature of patron-client relationships is the ability for the patron to offer the client access to something they want or need (Lewis 2012). Patrons have more governing power, social autonomy, connections, money and influence than clients which means that people need a patron's support to access a variety of services (UN 2000). For example, patrons provide their clients with access to jobs, homes, education and protection (UN 2000). This is possible because the state in Bangladesh is particularly weak and services are often provided by a number of organizations. This means that patron-client relationships extend into every social domain and define relational networks, from daily life in villages to politics in Dhaka (UN 2000).

Patronage is 'a central coping strategy for the urban poor' (Banks 2012: 2). Poor people need patrons to access health care; a weak state and their status in society mean that they depend on their associations with patrons to survive. However, these relationships are often exploitative and people are forced to pay inflated prices for basic human services (Banks 2012). In many ways, patronage is defined by a person's class or caste, which means that someone from a lower class is more likely to require the services of a patron (Banks 2012). Additionally, by forming the right connections, or accessing patronage, a person from a lower class may be able to mobilize themselves in society and govern access to services 
rather than being the recipient (Banks 2012). This research explores the involvement of mastaans in Bangladesh's landscape of patronage.

One final particularly significant concept is child labor because millions of children in Bangladesh work (Ruwanpura and Roncolato 2006). Some estimates have put the number of child workers at one in every five children (Salmon 2005). However, the Internal Labour Organisation (ILO) (2006) argued that there are at least 7.4 million children engaged in some form of work, with over three million of these children carrying out labor and over one million engaged in hazardous labor. They argue that there is a clear distinction between 'work' and 'labor': work may benefit a child whereas when work harms a child, denies them the right to play or participate in education, or affects their mental or physical development, it becomes labor and should be avoided at all costs (ILO 2006).

Research suggests that children in Bangladesh work in a variety of jobs, ranging from domestic labour to agricultural work (Khanam 2005). Children clean cars, shine shoes, drive rickshaws, collect rubbish, beg at car windows, and work in houses, restaurants, shops and factories (Khatun and Jamil 2013; Hai 2014). Patwary et al (2012) highlights street children's involvement in medical waste scavenging where young people forage in hospitals, dumping grounds and bins for syringes, medicine, cotton and plastic containers which they then sell for recycling.

Thus these three key concepts are essential to understanding Bangladeshi society; social protection, patronage and child labour. But what is the relationship between social protection, patronage and organized crime? How can we use theories of child labor to better understand the relationship between young people and mastaans? This chapter seeks to answer these questions and contribute to the debate about a criminology-development studies collaboration suitable for explaining crime and violence on a global scale to support the advancement of a 'Southern criminology'.

\section{Research methods}

This case study consisted of several components, broadly split into three phases:

\section{Phase 1: Participant observation}

I conducted a total of three years' worth of participant observation of Bangladeshi society and the criminal justice system, most of which occurred while I worked for an international development organization in Dhaka. ${ }^{\text {iii }}$ This observation was essential to understanding the 
social, political, economic and cultural factors that provide context to gangs and organized crime in Bangladesh. ${ }^{\text {iv }}$

\section{Phase 2: Interviews with adult practitioners}

I carried out a total of 80 interviews (38 semi-structured and 42 unstructured) and two focus groups, the first with six participants and the second with five. The participants included police officers, senior prison officers, military security officers, paralegals, NGO workers, police and prison reform workers, journalists, diplomats and community members. One of the participants, a children's rights worker, had lived on the streets as a child and during that time had been involved with a criminal gang. His perspective provided a unique perspective on this subject.

Phase 3: An embedded case study of street children and the organization that supports them I carried out an embedded qualitative case study with an organization that houses and supports 22 children from the streets and slums in Dhaka. The children were aged eight to 15; there were 12 and 10 girls. This case study included: a) participant observation carried out over a period of 12 months, during which I visited the organization on a weekly basis; b) five one-hour workshops; and c) semi-structured group interviews conducted with all 22 children. ${ }^{\text {vi }}$

\section{Mastaans and the market for protection}

This section considers the first research proposition: Mastaans are mafia groups that operate in a market for protection, patronage and violence. It will consider the notions of social protection and patronage and then deliberate on what this means within the context of organized crime. This section will explore the nature of mastaans and will discuss the role that these groups play in crime and violence, and in the market for protection.

Mastaans are a consistent feature in slum areas of Dhaka (Atkinson-Sheppard 2017a). In these areas, mastaan bosses use hierarchically structured groups to control and exploit slum dwellers (Atkinson-Sheppard 2017a). In 2006, Hallsworth and Young proposed that group offending often exists in three distinct, but inter-related echelons: 'peer groups', 'gangs' and 'organized crime'. I proposed an amended hierarchy: in Bangladesh, mastaan bosses exist at the highest echelon and work in collusion with corrupt politicians. These groups deal in a market for protection and violence (Atkinson-Sheppard 2017a). To conduct their activities 
mastaans hire gang members who work at the street level and conduct a variety of crime and violence: toll collecting, political violence, drug dealing (Atkinson-Sheppard 2016). At the lowest echelon, vulnerable street children are used in the fight for political advantage and are hired by mastaans to carry out violent and criminal acts. These young people are 'illicit child labourers' (Atkinson-Sheppard 2016).

Mastaans are mafia-type organizations which have three main roles in Bangladeshi society. Firstly, they protect economic transactions and are involved in the resolution of disputes. Secondly, they act as patrons governing access to basic human services and, finally, they engage in a variety of crime and violence (Atkinson-Sheppard 2017a). Thus, the role of mastaan groups is multi-faceted involving both criminal and non-criminal social dimensions (Atkinson-Sheppard 2017a). The field work data demonstrated many instances in which mastaans protect illegal industries. For example, the participants explained how mastaans provide protection for criminal groups such as drug dealers or organized beggars. In addition, the data illustrated the role that mastaans play in resolving disputes; that is, if an individual is not paid money they believe they are owed, it is possible for them to hire the services of a mastaan to resolve the dispute. This might be in the form of threats, violence or the mastaan exerting their influence and authority over the accused. The fieldwork data also demonstrated that mastaans provide slum dwellers with access to basic human services such as housing, electricity and water. Furthermore, mastaans also provide a way for marginalized citizens to build social connections and access the labor market, thus fulfilling a social protective function (Atkinson-Sheppard 2017a).

The young people in this study spoke frankly about the benefits of aligning themselves with a mastaan group. As one person explained: 'So many boys are involved in these groups because they don't have anything, they need money, they need clothes and they need food. These groups give them money and shelter [protection], that's why people join them' vii However, these groups also provide protection in other forms; from rival gangs and from the threat of criminal prosecution; and they fulfil a social protection function by acting as patrons and providing street children access to the labor market, housing, basic services and social connections. Patron-client relationships are as important to gang members as they are to young people operating in mainstream society; patronage defines the ways in which life, and criminal activities, are governed in Bangladesh. Thus, street children engage in 
organized crime groups as a way to secure 'protective agency' essential for their survival on the streets (Atkinson-Sheppard 2017c).

\section{'Illicit child laborers'}

This section discusses the second proposition that mastaan groups hire street children to commit crime for them. The term 'illicit child labourer' (Atkinson-Sheppard 2016) is therefore useful in this context. As previous discussions have highlighted, child labor is endemic in Bangladesh and millions of young people are engaged in labor or work, particularly those that live on the streets. The types of work these children engage in range from begging to domestic work as one of the young people explained: 'There are so many children working on the street; on busses to collect money from the passengers, collecting rubbish, begging, car cleaners, selling flowers, selling chocolates'. viii However, based on the findings in this study, children are also hired for the purposes of organized crime.

The young people described the types of crime that street children are hired to commit, as one young person explained: 'They [children] get money to do many crimes: Hijacking, theft, drugs, weapons ${ }^{\text {ix }}$. Another young person said that 'the younger ones are thieves and hijackers and the older ones own them, they rule them, ${ }^{\text {, }}$, which demonstrates children's involvement in theft and robbery (often described as hijacking by both the adult and child participants) on the instruction of a boss. Another young person described the power dynamics among gangs: 'Street children will do anything, like stealing, selling drugs, hijacking anything the older ones want. If they [older gang members] see something they want, they will just get the street boys to do it, or steal it for them. The young boys just do it because they want the money, ${ }^{x i}$. There were clear 'chains of command' among mastaan groups: 'The boss wants a robbery, kidnapping, hijacking or drug selling so he orders the juniors to do it for him ${ }^{\text {xii }}$. Many of the young people associated young people's involvement with mastaan groups as a way to secure protection - as discussed above - but also because of fear: 'They obey the boss because the boss gives them money and the boss shows the power: "I have the gun; you have to do this otherwise I will kill you." That's why the younger ones do the crime because they are fearful of the boss. ${ }^{\text {xiii, }}$

Street children conduct theft or robbery, and in many instances, provide a share of their earnings from these crimes to older gang members, illustrated by one young person: 
So many times the young boys earn lots of money by stealing and robbing. They steal a necklace and then they give the money to the boss who will distribute it to the other members of the group. The children also go to construction sites at night to steal bricks, they get lots of money from this. ${ }^{\text {xiv }}$

Another participant explained the following: 'If someone from the group spots someone carrying lots of money home, they will just stop him and say "give me the money". If he does not agree, if he runs, then the group will run after him and they will stab him for the money ${ }^{\mathrm{xv}}$.

Street children are also hired by mastaans to collect extortion money or engage in 'toll collecting'. The participants discussed how mastaans collect taxes or 'tolls' from local businesses, who operate on the streets and in slums. They explained how business owners, and in some cases slum residents are forced into paying money to mastaans for fear of violent repercussions. In some instances, mastaans hire street children to collect the money for them, illustrating a form of 'illicit child labour' (Atkinson-Sheppard 2016). The participants also described instances of 'land grabbing' where mastaan groups threaten land-owners with violence in order to acquire land, particularly in slum areas as one participant explained:

They [mastaans] do land grabbing. If mastaans want a piece of land, sometimes they kidnap the landowner's son or daughter and then demand either the land or ransom. This type of crime is rarely reported. Small land owners give them money for fear; they are scared of the land grabbing mastaans. ${ }^{\text {xvi }}$

In some instances, street children are hired by mastaans to assist this process. Children, on the instruction of mastaans, congregate on a particular piece of land until the landowner has no choice but to relinquish the land (Atkinson-Sheppard 2016). Finally, and perhaps most concerning is when children are hired to conduct contract killings. The data demonstrated that this is not a common occurrence but does occur; children are hired to commit murder on behalf of mastaan bosses, often in revenge killings or linked with land grabbing incidents as a police officer explained: ${ }^{\text {xvii }}$

Last year I arrested a boy, Babul. ${ }^{\text {xiii }}$ He was 16 years old and was charged with killing a 50-year-old man. This was a 'land grabbing' incident. The victim wanted the 
same piece of land as another man, the man spoke to a mastaan who got Babul to kill the victim so that he could have the land. ${ }^{\text {xix }}$

According to the police officer, Babul lived on the streets and was a drug addict. For conducting the murder Babul was paid 10000 taka (approximately £1000), 'then he felt like a rich man ${ }^{\mathrm{xx}}$. Thus, mastaan groups conduct a variety of criminal offences and, in many instances, use children to carry out these activities for them. When this occurs, I propose that these children should be conceptualized as 'illicit child labourers' as opposed to gang members, victims or offenders (Atkinson-Sheppard 2016).

The labor that street children are hired to do is often menial, unskilled or semi-skilled and demeaning. It denies their right to an education and puts them at risk of harm on both a physical and psychological level. The long-term consequences of children's involvement in organized crime remain unknown. However, protection for street children who commit crime must be sought: for the children themselves, their victims and to stop the spread of organized crime in Bangladesh. There are, however, several barriers to achieving this. For example, street children's involvement in mafias is not sufficiently documented within the ILO definition of the Worst Forms of Child Labour (ILO 1999), nor is the issue given the attention it deserves on an international stage. This means that opportunities to protect millions of children are missed, both in Bangladesh and on a global scale.

The proposition that children are the laborers of Bangladeshi organized crime groups highlights the importance of a collaboration between criminology and development studies. Understanding the criminality of exploitative child labor is an essential part of appreciating children's lives in Bangladesh. It is thus unsurprising that it features in a discussion of young people's involvement in organized crime. Without an understanding of child labor, the views of the young people discussed in this study would have been misinterpreted at best or misunderstood at worst.

The question remains as to how to develop an approach worthy of explaining crime on a global scale. The discussions in this chapter have provided a tangible option, particularly when the subject of concern is street children's involvement in organized crime. One avenue which could be further explored is the collaboration of criminology and other disciplines. While this approach is not necessarily new (and historically criminology has, and will 
continue to have strong associations with disciplines such as law, ethnography) there are some areas in which this type of approach may assist the development of a global understanding of crime and violence. One possibility, rarely discussed in the literature, is an association between criminology and children's geographies. Fraser and Piacentini (2014: 56) draw our attention to the changing, and increasingly global nature of crime and the "new geographies of mobility and immobility that exist in the global era, and their implications for crime and crime control', and Alcano (2014: 38) highlights how gangs in Indonesia use 'the spaces and resources that are available to them to find a way (metaphorically and literally) to be part of a society and not subvert it altogether'. Both of these points raise several questions for our discussion. Is it plausible that Dhaka's laborers will migrate to conduct their work in other places, across the national boundaries of Bangladesh and into the global sphere? What then are the implications for the spread and control of organized crime, and the exploitation of children across the globe? Perhaps children will remain bounded by their 'class-stratifications' (Fraser and Piacentini 2014: 56) and face a life of immobility, confined by the streets in which they were born. More focus on what space, mobility and 'spatial immobility' (Fraser and Piacentini 2014: 73) mean for street children would help to refine these discussions and pave the way for future research. Using 'spatial boundedness' (Phillips and Webster 2014: 181) to explore the restrictions that street children face in moving around the city and through class and gang stratifications would help us to understand the identity formation of these children which, as Palmer (2014: 134) argues, is both 'acquired and self-constructed' by the subcultures of the groups they associate with. The association between organized crime, patronage and mobility is something which requires further research. Questions for consideration include: what is the relationship between patronage, mobility and gangs, and how do these processes and relationships affect social inclusion for street children in Dhaka? How do children use organized crime groups to exert their agency and increase their mobility?

Furthermore, the topic of street children and the spaces they inhabit, alongside discussions of 'street youth mobility' (van Blerk 2013:557) has demonstrated the importance of considering the ways in which street children navigate life in urban areas, within families (van Blerk 2012) and how they use public spaces (van Blerk 2005). A topic often missing from criminological discourse. The fieldwork data illustrated that mastaan groups support street children to become 'more mobile' and thus more able to navigate life on the streets, feel included, secure an income and ensure their own protection. For example, an older gang 
member may provide a younger member with a job, support, access to housing and facilitate connections with men (such as mastaans) who hold powerful positions in Bangladeshi society. This raises an important conceptual point. Previous discussions about street children's mobility have demonstrated how life on the streets is governed by relationships that assist a child's survival (van Blerk 2013, 2005). This study was able to show that, for Dhaka's street children, mobility is closely associated with gangs and organized crime. These criminal groups are the vehicle by which children gain access and then are able to exert more control (agency) over their lives and move into places and situations which are more conducive to their survival. It was beyond the scope of this research to test how these relationships assist children's mobility, which parts of their mobility are voluntary and which are forced (van Blerk 2005) - how the power dynamics of gangs affect a street child's agency and the long-term effects that using gangs as a vehicle for mobility has on children's lives.

\section{Conclusion}

Research derived from development studies frequently considers poverty, culture and livelihoods, while criminology focuses on crime and how it is constructed, facilitated, learned and developed, often within the global North. There is a lacuna between the two disciplines yet associations should be more widely encouraged so that we can learn more about the global issues related to crime and violence.

This study contributes to the field of Southern criminology because it addresses an oftenoverlooked issue: the criminal exploitation of street children in Bangladesh. There is a paucity of street children's narratives in criminological research, and the discipline can only benefit if the views of these children are more widely examined. One of the most important achievements of development studies is the paradigm shift away from seeing street children as solely offenders or victims (Ennew and Swart-Kruger 2003). The notion of the street child's career can then be used as a way to explain how children 'move out of home space, into street space, and through a variety of stages, activities and images - depending on experience and increasing age - to the processes of leaving the street, which are not unitary and far from being always the result of adult intervention' (Ennew and Swart-Kruger, 2003:8). Conclusions drawn from this paradigm conceptualize street children as social agents fully engaged in constructing their reality on the streets (Ennew and Swart-Kruger, 2003). These studies also discuss the construction of identity via social spheres, work, 
gender, groups, home, sexuality and the streets (Jones, Thomas de Benitez and Herrera 2008). This questions the notion of street children as a homogenous group, viewing them instead as diverse individuals with differing skills, vulnerabilities and needs who move from childhood to adolescence and beyond. Criminology would benefit from following a similar approach.

The majority of studies into criminal gangs come from the developed world (Hagedorn, 2008), meaning that issues that are salient in a developing country such as Bangladesh are often missing from the debate. By expanding the boundaries of criminology to include concepts such as social protection, patron-clientism and child labor, the understanding of how criminal networks operate in the developing world can be enhanced. On a wider scale, the theories proposed in this study may well apply to other developing countries which share similar cultural characteristics, particularly those in South Asia. A significant step forward would be for this research to promote discussions at a regional level through, for instance, meetings of the Asian Criminological Society.

Moreover, research with street children would benefit from a closer collaboration with criminology. Criminologists frequently consider how, and why, young people engage in crime and violence. Development studies frequently prioritize culture, masculinity and livelihoods, often in the developing world, while criminology focuses on crime and how it is constructed, facilitated, learned and developed, often within the western world. There is a lacuna between the two disciplines. Insights from both disciplines enhance the understanding of street children's involvement in crime and violence. For example, more detailed discussion about power relations within gangs and the ways in which this affects the child workers of these groups, and greater exploration of how children's identities are shaped within gangs would be useful to end users in policy and practice. Additionally, studies that combine subcultural theories and theories of agency to explore the collective agency of groups of street children, operating among the context of gangs and organized crime would benefit criminology and development studies alike.

The fact remains that both criminology and development studies suffer from a type of ethnocentricity which as Carrington, Hogg and Sozzo (2016: 5) suggests 'privileges ideas of temporal succession: "developed" and "developing", "industrial" and "industrializing", "first' and "second" worlds and "the third world". In other words, the global North 
designates the normative benchmark (the developmental destination) to which the rest of the world will naturally aspire'. Thus, any collaboration between these two disciplines must proceed with caution and respect for their integral, and often negative shortcomings. One of the main aims of Southern criminology is to re-balance criminology, to re-write the wrongs of the colonial era and all of its implications on crime and violence. Thus, while I advocate that the first steps in developing such an approach is by working with what we have, I also propose that discussions must remain reflexive and critical in both the understanding and application of these perspectives.

The conceptualization of children as 'illicit laborers' may well be useful for other countries in the global South where child labor is endemic and organized crime is pervasive. It is likely that, within similar circumstances, children will also be operating as laborers in organized crime groups. But there is a wider question underpinning this debate. Perhaps all children involved in organized crime are laborers. Do they not all work and earn an income? How could we develop a criminology that explains children's involvement in organized crime in all places, and on a global scale? 


\section{References}

Alcano MC (2014) Youth gangs and streets in Surabaya, East Java: Growth, movement and spaces in the context of urban transformation. Antropologia 1(1): 33-58.

Aptekar L and Heinonen P (2003) Methodological implications of contextual diversity in research on street children. Children, Youth and Environments 13(1).

AusAID (2005) Make Me Visible. Australia.

Atkinson-Sheppard (2017a) Mastaans and the market for social protection: Exploring Mafia groups in Dhaka, Bangladesh. Asian Journal of Criminology. DOI: 10.1007/s11417017-9246-9.

Atkinson-Sheppard S (2017b forthcoming) Street children and Dhaka's gangs: Using a case study to explore Bangladeshi organised crime. SAGE Research Methods Cases.

Atkinson-Sheppard S (2017c) Street children and 'protective agency': Exploring young people's involvement in organised crime in Dhaka, Bangladesh. Childhood. DOI: $10.1177 / 0907568217694418$.

Atkinson-Sheppard S (2016) The gangs of Bangladesh: Exploring organised crime, street gangs and 'illicit child labourers' in Dhaka. Criminology and Criminal Justice 16(2) 233-249. DOI: 10.1177/0907568217694418.

Banks N (2012) Urban poverty in Bangladesh: Causes, consequences and coping strategies. BWPI Working Paper 178. The University of Manchester: Brooks World Poverty Institute.

Barrientos A and Hulme D (2008) Social protection for the poor and the poorest in developing countries: Reflections on a quiet revolution. BWPI Working Paper 30. Manchester. The University of Manchester: Brooks World Poverty Institute.

Cain M (2000) Orientalism, occidentalism and the sociology of crime. The British Journal of Criminology 40(2): 239-260. DOI: 10.1093/bjc/40.2.239.

Carrington K, Hogg R and Sozzo M (2016) Southern Criminology. British Journal of Criminology 56(1): 1-20. DOI: 10.1093/bjc/azv083.

Connell R (2007) Southern Theory: The Global Dynamics of Knowledge in the Social Sciences. Sydney, Australia: Allen and Unwin.

Cressey DR (1967) Methodological problems in the study of organized crime as a social problem. The Annals of the American Academy of Political and Social Science. 374(1): 101-112. DOI: 10.1177/000271626737400110. 
Densley JA (2012) 'It's a gang life but not as we know it': The evolution of gang business. Crime and Delinquency 60(4): 517-546. DOI: 10.1177/0011128712437912.

Ennew J and Swart-Kruger J (2003) Introduction: Homes, places and spaces in the construction of street children and street youth. Children, Youth and Environments 13(1).

Feldman S (1997) NGOs and civil society: (Un)stated contradictions. American Association of Political and Social Sciences 554: 46-65.

Fraser A and Piacentini T (2014) We belong to Glasgow: The third space of youth 'gangs' and asylum seeker, refugee and migrant groups. In Phillips C and Webster C (eds) New Directions in Race, Ethnicity and Crime: 55-79. London: Routledge.

Gambetta D (1993) The Sicilian Mafia. London: Harvard University Press.

Hagedorn JM (2008) A World of Gangs, Armed Young Men and Gangster Culture. Minneapolis: University of Minnesota Press.

Hai, M. A. (2014). Problems faced by the street children: A study on some selected places in Dhaka City, Bangladesh. International Journal of Scientific \& Technology Research, $3(10), 45-56$.

Hallsworth S and Young T (2006) Urban Collectives: Gangs and Other Groups. London: Metropolitan Police Service.

The International Labour Organisation (ILO) (1999) The Worst Forms of Child Labour Convention (Convention 182). USA: ILO.

The International Labour Organisation (ILO) (2006) Baseline Survey on Child Domestic Labour in Bangladesh. Bangladesh: ILO.

Jahan R (2001) Bangladesh: Promise and Performance. Dhaka: The University Press. Jones GA, Thomas de Benitez S, Herrera E (2008) 'Being in public': The multiple childhoods of Mexican 'street' children. Economic and Social Research Council Identities and Social Action Programme. London: Economic and Social Research Council.

Khanam K (2005) Child labour in Bangladesh: Trends, patterns and policy options. Asian Profile 34(6): 593-608.

Khatun MT and Jamil H (2013) Lifestyle of the street children in Khulna City. Bangladesh Research Publications Journal 9(1): 50-56.

Lewis D (2012) Bangladesh: Politics, Economy and Civil Society. Cambridge: Cambridge University Press. 
McIllwain JS (1999) Organized crime: A social network approach. Crime, Law and Social Change 32(4): 301-323. DOI: 10.1023/A:1008354713842.

McIntosh M (1975) The Organisation of Crime. Macmillan: London.

Moniruzzaman M (2009) Party politics and political violence in Bangladesh: Issues, manifestation and consequences. South Asian Survey 16(1): 81-99. DOI: $10.1177 / 097152310801600106$.

Nelken D (2009) Comparative criminal justice: Beyond ethnocentrism and relativism. European Journal of Criminology 6(4): 291-311: 1477-3708. DOI: 10.1177/1477370809104684.

Organisation for Economic Cooperation and Development (OECD) (2009) Promoting ProPoor Growth: Social Protection. United States: OECD.

Palmer A (2014) Configuring ethnic identities: Resistance as a response to counter-terrorist policy. In Phillips C and Webster C (eds) New Directions in Race, Ethnicity and Crime: 118-138. London: Routledge.

Paoli L (2002) The paradoxes of organized crime. Crime, Law \& Social Change 37(1): 5197. DOI: $10.1023 / \mathrm{A}: 1013355122531$.

Park RE, Burgess EW and McKenzie RD (1925) The City: Suggestions for Investigation of Human Behaviour in the Urban Environment. Chicago: University of Chicago Press. Patwary, M.A., O’Hare, W.T., Karim, S.A. and Sarker, M.H. (2012) The Motivations of Young People Moving into Medical Waste Scavenging as a Street Career. Journal of Youth Studies. Vol. 15. (5): 591-604.

Phillips C and Webster C (2014) New direction and new generations - Old and new racism?

In Phillips C and Webster C (eds) New Directions in Race, Ethnicity and Crime. London: 178-186. London: Routledge.

Ruwanpura KN and Roncolato L (2006) Child rights: An enabling or disabling right? The Nexus between child labour and poverty in Bangladesh. Journal of Developing Societies 22(4): 359-372. DOI: 10.1177/0169796X06071523.

Said E (1978) Orientalism: Western Conceptions of the Orient. London: Routledge.

Salmon C (2005) Child labour in Bangladesh: Are children the last economic resource in the household? Journal of Developing Societies 21(1-2): 33-54. DOI:

$10.1177 / 0169796 X 05053066$.

Sergi A (2015) Mafia and politics as concurrent governance actors. Revisiting political power and crime in Southern Italy. In van Duyne PC, Maljević A, Antonopoulos GA, 
Harvey J, von Lampe K (eds) The Relativity of Wrongdoing: Corruption, Organised Crime, Fraud and Money Laundering in Perspective: 43-72. Oisterwijk: Wolf Legal Publishers.

Smith DC (1975) The Mafia Mystique. New York: Basic Books.

Thrasher FM (1927) The Gang. Chicago: University of Chicago Press.

Thomas de Benitez S (2011) State of the world's street children: Research. Street Children Series. London: Consortium for Street Children.

Travers M (2016) The idea of a Southern criminology. Paper presented at the Asian

Criminology Society's Annual Conference: 17th-21st June. Beijing, China.

UNICEF (United Nations International Children's Emergency Fund) (2012a) Child Rights Bangladesh. Available at http://www.unicef.org/bangladesh/children_4878.htm (accessed 7 April 2017).

UNICEF (2012b) Child Sexual Abuse, Exploitation and Trafficking in Bangladesh. UN (United Nations) (2000) Enhancing Social Protection and Reducing Vulnerability in a Globalizing World. Report to the Secretary General to the Thirty-ninth Session. Washington: United Nations Economic and Social Council.

UN-HABITAT (United Nations Human Settlements Programme) (2002) Urban Indicators Database. [Online]. Available at: https://unhabitat.org/books/global-urban-indicatorsdatabase/global-urban-indicators-database/

UN-HABITAT (United Nations Human Settlements Programme) (2003) Slums of the World: The Face of Urban Poverty in the New Millennium? Nairobi: UN.

van Blerk L (2005) Negotiating spatial identities: Mobile perspectives on street life in Uganda. Children's Geographies 3(1): 5-22. DOI: 10.1080/14733280500037091. van Blerk L (2012) Berg-en-See street boys: Merging street and family relations in Cape Town, South Africa. Children's Geographies 10(3): 321-336. DOI: 10.1080/14733285.2012.693381.

van Blerk L (2013) New street geographies: The impact of urban governance on the mobilities of Cape Town's street youth. Urban Studies 50(3): 556-573. DOI: 10.1177/0042098012468895.

van Schendel W (2009) A History of Bangladesh. Cambridge: Cambridge University Press. Varese F (2001) The Russian Mafia: Private Protection in a New Market Economy. Oxford: Oxford University Press. 
Varese F (2010) What is organised crime? In Varese F (ed) Organised Crime: Critical

Concepts in Criminology, Vol. 1: 1-33. London: Routledge.

White S (1999) NGOs, civil society, and state in Bangladesh: The politics of representing the poor. Development and Change 30(2): 307-326. DOI: 10.1111/1467-7660.00119. Wright A (2006) Organised Crime. Cullompton: Willan. World Bank (2012) Social Protection and Labour. World Bank: Bangladesh.

\footnotetext{
${ }^{\mathrm{i}}$ This chapter defined social protection, patronage and child labor as concepts derived from development studies. This is done to ensure clarity for the reader; however, I acknowledge that all three concepts are also relevant to other fields such as childhood studies and ethnography.

ii The term 'street child' is a contentious for many reasons. Scholars note the diverse backgrounds of these children and the different ways they engage with the streets (Thomas de Benitez 2011). In addition, the lives of street children are far from static, their relationships with the streets evolve as they grow up (Ennew and SwartKruger 2003). Thus, these children must be viewed as individuals rather than as a homogeneous group (Ennew and Swart-Kruger 2003). It is preferable to consider the range of 'street connections' that young people have (Thomas de Benitez 2011) and, in this study, is it important to note the ways in which the children were 'street connected'; some lived 'off' of the streets at an organization and rarely returned home, others still played 'on' the streets while still engaging with the organization, in addition, several of the children still worked 'on' the streets during the time of this study (for a more in-depth discussion of children 'of', 'on' and 'off' the streets, see Aptekar and Heinonen 2003). For the purpose of clarity, the term 'street child' is used within these discussions; however, it must be read with caution and considered in light of the variety of connections that children have whilst being 'street involved' (Aptekar and Heinonen 2003).

iii The name of the organization is intentionally excluded from this paper to protect the anonymity of the participants in this study and the organization itself.

iv All phases of this study adhere to the British Society of Criminology's Ethical Code and was submitted to the King's College London Ethical Committee where it gained ethical approval.

${ }^{v}$ The names of the participants are excluded from this paper to uphold confidentiality and protect the anonymity of all who participated in this study.

${ }^{\mathrm{vi}}$ For more details about the research with the children including engagement techniques, confidentiality and ethics, please see Atkinson-Sheppard S (2017b forthcoming) Street children and Dhaka's gangs: Using a case study to explore Bangladeshi organised crime. SAGE Research Methods Cases.

vii Group interview 3 with the children.

viii Group interview 1 with the children.

${ }^{\text {ix }}$ Group interview 2 with the children.

${ }^{\mathrm{x}}$ Group interview 5.

${ }^{x i}$ Group interview 5 with the children.

xii Group interview 6 with the children.

xiii Group interview 6 with the children.

${ }^{x i v}$ Group interview 4 with the children.

${ }^{\mathrm{xv}}$ Group interview 4 with the children.

${ }^{x v i}$ Semi structured interview 10 .

${ }^{x v i i}$ For a more detailed discussion please see: Atkinson-Sheppard S (2016) The gangs of Bangladesh: Exploring organised crime, street gangs and 'illicit child labourers' in Dhaka. Criminology and Criminal Justice 16(2)

233-249. DOI: 10.1177/1748895815616445.

xviii Not his real name.

xix Semi structured interview 11 .

${ }^{\mathrm{xx}}$ Semi structured interview 11.
} 